\title{
Determinants of tourism demand in Croatia
}

\author{
Maja Pervan, Ena Jurić \\ University of Split, Faculty of Economics, Business and Tourism, Split, Croatia \\ Received: July 25, 2021. Revised: November 13, 2021. Accepted: December 7, 2021. Published: December 29, 2021.
}

\begin{abstract}
Due to its significant contribution to the prosperity and growth of economies, tourism industry has always been the one that attracted the attention of many practitioners and researchers who have tried in different ways and from different aspects to identify the key variables that determine tourism demand. The importance of tourism is especially evident in Croatia for which the contribution of travel and tourism industry to GDP and total economy employment amounts $25 \%$ and $25.1 \%$ respectively. Having in mind the importance and the role that tourism has, the main objective of this research is to examine the influence of different factors on tourism demand for Croatia. The analysis is conducted on the sample of 16 countries of origin and 9 competitor countries during the period 2012-2019 with the application of dynamic panel data model. All variables encompassed in the model i.e., price, income, corruption, terrorism and investments, show statistically significant influence on tourist arrivals in Croatia.
\end{abstract}

Keywords - Croatia, tourism demand, panel analysis

\section{INTRODUCTION}

A CCORDING to microeconomic theory, consumer's decision about the quantity of product or service to buy depend on its price and other factors like income, consumers' preferences, information, prices of substitutes and complements and government policies [1]. Unlike the majority of other goods and services, consumption of the tourism product includes buying of goods and services that are expended at the place of destination. In general, factors influencing tourism demand can be divided into motivations and determinants. While motivations deal with aspects of psychological nature such as the reasons why are people travelling and what needs are they trying to satisfy, determinants represent factors affecting demand which are not just economic type, but also political, demographic, geographical and sociological [2]. The phenomenon of growing demand for tourism around the world in recent decades encouraged growth of research interest in tourism. Since it is one of the most significant topics in tourism research, tourism demand modelling and forecasting has allured researchers from both academic and practice backgrounds [3]. Moreover, as nowadays a tourist product presents a compound fusion of complementary goods and services that are serving a highly segmented market, in order to adequately analyse tourist demand, the researchers must use a variety of refined and sophisticated methods and techniques [4].

According to the data of Croatian Bureau of Statistics, over the last two decades, Croatia has recorded a steady increase in the number of tourist arrivals and overnight stays. Since 2000, the number of tourist arrivals has almost tripled - from 7.1 million in 2000 to 19.6 million in 2019. Foreign tourists prevail with a share of $89 \%$ in total number of tourist arrivals in 2019. The majority of tourists visit Croatia during the summer season and stay in private accommodations, hotels and camping sites. World Travel \& Tourism Council's data show that, in 2019, the contribution of travel and tourism industry to Croatian GDP amounted $25 \%$, with a share of $25.1 \%$ in total economy employment. From these numbers it is obvious that Croatian economy is highly dependent on tourism.

Having previously stated in mind, the main aim of this paper is to investigate the factors that influence foreign demand for Croatian tourist product. The formulated model, besides traditional tourism demand determinants such as price and income, considers also Croatian hospitality investments as well as corruption perception and terrorism index of competitor destinations. Moreover, as the latter two determinants have been rarely investigated in general, and to the best of authors' knowledge have never been examined for Croatia in particular, by their inclusion into the proposed model, we directly contribute to the existing body of knowledge by shading new lights on their influence on tourism demand. Aside from being the first study in the domestic literature that observe terrorism index and corruption perception variables as determinants of tourism demand, this study also adds to the research on the demand for tourist product in less developed market.

The rest of the paper is structured in the following way. The section 2 provides overview of the literature related to tourism demand, while the section 3 give insights into the methodology and variables used in the empirical part of the analysis. Section 4 brings the results of the conducted analysis while the last section concludes.

\section{LITERATURE REVIEW}

There were numerous tourism demand modelling and forecasting studies in recent decades and all of these models differ mainly in terms of regressand and regressor variables, observed periods and data levels, empirical methodologies and emitting/receptive country pairs [5]. Generally, international tourism demand is usually measured in terms of the number of 
tourist visits, tourist expenditure by visitors and the number of overnight stays by tourists from the origin country in the destination. On the other hand, commonly used explanatory variables are the origin country population, the origin country earnings, price, consumer preferences, etc. [6]. The majority of studies were focused on modelling and forecasting inbound tourism in traditionally receptive countries.

Many authors were lately using dynamic panel data models for modelling tourist demand in their studies. Garín-Muñoz [7], [8] formulated a dynamic model of international tourism demand to Canary Islands for the 15 most important origin countries of tourists during the period 1992-2002 and the dynamic model of German demand for tourism in Spain for the period 1991-2003. In both studies, she applied a GMM-DIFF estimator. The results of the research showed that tourism at Canary Islands could be viewed as a luxury good, while a lagged dependent variable was explained in terms of high devotion of visitors to the destination. Moreover, the empirical findings obtained after modelling German demand for tourism in Spain were quite similar to the previous results, confirming once again that tourism demand in the past period has a notable effect on current tourism demand. Many authors introduced specific variables as determinants of tourism demand depending on their research objectives. Some studies were focused on special forms of tourism e.g., academic tourism [9], [10], while some others were interested in some very specific questions e.g., how do climatic variations between origin country and destination affect tourism demand [11]. Precisely, with the application of dynamic panel data model, [9] carried out empirical analysis dealing with the demand of academic tourism in Galicia. As a dependent variable, indicating tourism demand, the authors used the number of external students from 36 various countries who annually enrolled into any of the three Galician universities in the period 2001-2009. As explanatory variables, beside economic variables (i.e., relative price index, the per capita GDP of each origin country and travel costs), the authors included non-economic factors closely related to academic tourism (i.e., the differential attractiveness of the local university, system implementation Bologna, Erasmus programme, etc.). The obtained results indicated that academic tourism depended largely on determinants that were not exclusively economic. The prevalence of non-economic factors over economic ones, where also confirmed by [10]. In one of their latest models, using a panel data and DIFF-GMM, the authors [11] included data on origin country climate, destination climate, and difference between destination climate and home country climate as explanatory variables and showed that all of them have significant impact on demand for Mainland Chinese tourism among Hong Kong residents. Some researchers were also addressing relations between tourism demand and social issues like corruption and terrorism. Recently, several studies on impact of corruption on tourism have been published [12], [13], [14], [15]. In order to give their contribution to this subject, [12] employed panel quantile regression estimation techniques on a data set of 62 nations over the period 1998-2011 and discovered that the nonlinear relation between corruption and tourism demand is significant only at the 50th and 75th quantiles. Reference [14] investigated the influence of corruption on tourism using a panel data set of over 100 countries during the period 19952010. The results indicated that a 1-point increase in the Corruption Perception Index (which implied a reduction in corruption), resulted in a $2 \%$ to $7 \%$ increase in tourist inflows. Reference [15] analysed the corruption impact on tourism demand for more than 130 countries from 1999 to 2009 by using panel least square and fixed effects regressions. Their findings suggested that corruption has an important impact on tourism demand. The influence of terrorism on tourists' decisions and choices has also been part of research interest [16]. In order to analyse factors influencing the number of tourist visits to Turkey from the top 25 countries of origin between 1998 and 2017, [17] employed an augmented gravity model using panel data. The empirical results showed that terrorist assaults are the most relevant factor for tourism demand in Turkey, triggering major reductions of tourist arrivals. Reference [18] used panel data from 139 countries during the period 1999-2009 in order to measure the extent to which terrorism and political conflicts in country can affect tourism industry. The results revealed that terrorism, after a certain threshold value, considerably decreased the value of tourism revenue and the number of tourist arrivals. Authors from [19] examined the impact of corruption, crime and terrorism on international tourist arrivals for 171 origin/destination countries during the period between 1995 and 2016. The results demonstrated that tourists are prone to travel to countries with similar levels of safe and secure environment as exist in their home country.

Some authors also conducted empirical analysis on tourism demand modelling and forecasting in Croatia. These authors used various methodologies such as autoregressive distributed lag (ARDL) approach [20], the Box-Jenkins approach [21], [22] and panel data approach [23], [24]. While [21] were focused on finding the most appropriate SARIMA model in describing German tourists' arrivals to Croatia, [22] tried to determine how much physical tourist traffic can be presumed in Croatia over the next five years based on tourism demand, accommodation capacities and seasonality of tourism. On the other hand, [20] showed that tourism demand is characterised by the positive and high-income elasticity, but not influenced by exchange rate and transportation costs. Based on methodological approach (similar to the one applied in this research), the variables and conclusions for the following two research were presented in more details. Using pooled annual data from 1998 to 2008 for four Croatian tourist regions (Dalmatia, Kvarner, Istra and Continental region) and applying the GLS regression method, [23] designed the model of demand for Croatian tourist product. As explanatory variables the authors used an average price by night in hotels, quality of tourist product approximated by average number of stars of the 
local hotels, GDP per capita of the origin country which generates the most tourists in region, the share of reservations and booking made online and the average age of the hotels. As a dependent variable, the number of overnight stays spent in hotels was employed. The main conclusions referred to the facts that income in Croatian key partnership countries is positively related to the tourism demand; that a rise in prices has negative impact on demand for tourism product, and that tourist businesses must take care of the usability of their own websites and have to ensure that customers can book services online. Using panel data analysis, [24] evaluated dynamic model with GMM estimator on a dataset of 19 origin countries of tourists for the period from 1994 to 2009. The author found that income elasticity ranged from $0.2 \%$ to $0.5 \%$ depending on the applied model, while the price elasticity of substitute destinations ranged from $0.8 \%$ to $1.2 \%$. In addition, results show that demand responds intensely to changes in relative prices and that capital investment has positive impact on the tourism demand in Croatia.

\section{METHODOLOGY AND VARIABLES DESCRIPTION}

Many of economic relations can be described as dynamic ones. Since previous consumption may affect the future one, when modelling tourism demand researchers usually incorporate dynamism by introducing a lagged dependent variable among explanatory factors. Garín-Muñoz [7], [8] explains the reasons that justify this inclusion. First, if the visitors are already familiar with the certain destination, their level of uncertainty is lower compared to the situation in which they visit a destination for the first time. Second, knowledge and information about the different tourist places spreads as people post their travel blogs on social media and/or talk about their holiday. In this way, an additional contribution to the reduction of the uncertainty for potential visitors is achieved. Finally, by neglecting the influence of past tourism, variables included in the model will be overestimated.

In line with stated, a lagged dependent variable $\left(\mathrm{Q}_{\mathrm{i}, \mathrm{t}-1}\right)$ is incorporated among the independent variables in the model which general form can be presented as:

$$
Q_{i t}=\alpha+\bar{\delta} Q_{i, t-1}+\sum_{n=1}^{N} \beta_{n} X_{i t}^{n}+\varepsilon_{i t} \quad \varepsilon_{i t}=v_{i}+u_{i t}
$$

where $\mathrm{Q}_{\text {it }}$ is the number of tourist nights from observed country $i$ in period $t$, with $i=1, \ldots, M, t=1, \ldots, T ; \delta$ is the speed of adjustment to equilibrium, $Q_{i, t-1}$ is the previous-year value of tourism demand i.e. tourist nights, $\alpha$ is a constant term, $\beta$ 's are the estimated coefficients, $X_{i t}$ 's are the predictors (i.e. income, price, corruption, terrorism, investments), $\varepsilon_{i t}$ stands for the disturbance, in which $v_{i}$ represents the unobserved country-specific effect while $u_{i t}$ denotes idiosyncratic error.

An obtained value of $\delta$ close to zero, would imply a high speed of adjustment toward its "optimal" level, while the value of $\delta$ close to one would indicate a very slow adjustment process. In the first case, the industry is fairly competitive, while in the second one, the industry is less competitive [25].

In models that incorporate dynamic specification, estimators such as OLS and GLS would produce biased and inconsistent estimates, hence, to overcome this problem, a Generalized Method of Moment procedure proposed by Arellano and Bond [26] is applied in this research. Still, to obtain a consistent and unbiased estimation, a GMM estimator require error to be serially uncorrelated [27]. Therefore, it is necessary to check for the serial correlation in the first-differenced residuals. The examination of the first-order and second-order serial correlation is commonly done with Arellano and Bond test statistics $\left(\mathrm{m}_{1}\right.$ and $\left.\mathrm{m}_{2}\right)$. GMM system estimator will be consistent only in case when there is no second-order serial correlation in residuals. It is worth mentioning that the presence of a first-order serial correlation does not indicate inconsistency of the estimates.

A second specification test conventionally used in this sort of analysis is a Sargan test, which checks for validity of instruments. A dynamic panel model will be adequately specified only if a null hypothesis cannot be rejected. This would suggest that all chosen instruments, i.e. overidentifying restrictions, are valid.

All variables used in (1) were chosen based on relevant literature and previous research, as well as due to data availability. Concise description of all variables, together with their expected influence on tourist demand i.e. number of tourist nights, is provided in the following sections. The dataset refers to the period from 2012 to 2019 and it includes data on 16 countries of origin and 9 competitor countries.

Dependent variable $\left(\mathrm{Q}_{\mathrm{it}}\right)$ is presented by the number of tourist nights from observed country $i$ in year $t$. Only those countries of origin (United Kingdom and United States, Sweden, Slovakia, Slovenia, Poland, Netherlands, Norway, Italy, Hungary, Germany, Finland, France, Czech Republic, Denmark and Austria) from which Croatia realised the most tourist nights in given period are included in the sample. ${ }^{1}$ The data were collected from Croatian Bureau of Statistics, which defines tourist nights as every overnight stay of a person registered in an accommodation establishment.

Income (I). According to microeconomic theory, an increase in income for most of goods would increase demand for them. These types of goods are called normal. On the other hand, demand for inferior goods will decreases if income increases. In order to capture the impact of income on tourist arrivals, the majority of previous studies (e.g., [23], [24]) used GDP per capita in the origin country as a measure for tourist's income. The same variable is applied in this research and the data for it were collected from The World Bank official website. Since tourist travelling are mainly observed as normal or luxury

\footnotetext{
${ }^{1}$ The number of tourist nights from Denmark, Finland, Norway and Sweden were consider all together, because in Croatian's National Tourist Board publications on significant market profiles, these four are scrutinized together in terms of Scandinavia market.
} 
good, the positive sign of this variable is expected.

Price $(P)$. For the relative price variable, we followed the approach of [9], [10] and [28]. The variable representing the price of living in Croatia relative to the price of living in countries of origin is calculated as:

$$
P_{i, t}=\frac{C P I_{C R O t}}{C P I_{i t}}
$$

where $\mathrm{CPI}_{\mathrm{CROt}}$ refers to the consumer price indices for Croatia, while $\mathrm{CPI}_{\mathrm{it}}$ stands for the consumer price indices for the origin country $i$. The data on CPIs were obtained from The World Bank official website. As price and demand are inversely related, meaning that a decrease in price leads to an increase in demand, the negative sign of this variable is anticipated.

Corruption (Corr). As a measure of corruption, we applied the Corruption Perception Index provided by the Transparency International. This index explains corruption in terms of the abuse of entrusted power for private gain. It ranks and scores territories/countries based on experts' and business executives' perception of how much a country's public sector is corrupted. In line with stated, this index is included in the model in order to examine how corruption perception in competitor countries affects tourism demand in Croatia. It is assumed that in the case of higher corruption perception in competitor destinations, tourists will prefer Croatia as their destination, ceteris paribus. For the calculation of this variable, average corruption perception indices of nine main competitor countries were taken into account. The competitors were selected following Croatian Institute for tourism [29] who finds Spain, Italy, Greece, Turkey, Malta, Bulgaria, Cyprus, France and Portugal as "Croatian wide competitive circle". Since the higher index indicates lower corruption perception, anticipated sign for this variable is negative.

Terrorism (Terr) influence is also included in the model by following the same approach as with corruption - how does terrorism in competitor destinations affect tourism demand in Croatia. As a measure of terrorism in competitor countries, their average rankings in the Global Terrorism Index (GTI) provided by Vision of Humanity were applied. According to Vision of Humanity, GTI is a composite measure made up of four indicators: incidents, fatalities, injuries and property damage. All of nine competitors from Croatian wide competitive circle were taken into account, except of Bulgaria, Malta and Portugal for which the data were incomplete. It is assumed that visitors will prefer safer countries, so in case of terrorism in competitor destinations, they will spend their holidays in Croatia. Vision of Humanity ranks countries with highest indices (high level of terrorism) on the top and countries with lowest indices (absence of terrorism) on the bottom of the list. Given that the GTI rank is used in this model, a negative sign of terrorism variable is expected.

Investment (Inv). The last variable included in the model refers to gross investment made by stakeholders involved in providing accommodation, food, catering, and other hospitality services in Croatia. Data were collected from Croatian Bureau of Statistics. Following [30] who suggest positive effect of public and private investments on tourism growth, and [24] whose model showed positive and significant effect of capital investments on tourism demand, the positive sign of this variable is expected.

\section{EMPIRICAL RESULTS AND DISCUSSION}

Descriptive statistics of variables used in modelling foreign demand for Croatian tourist product is presented in table 1. As all variables are presented in a form of natural logarithm, it is not surprising to observe a negative value for those variables whose original values were lower than 1 , as it was for the variable price.

The total number of tourist nights during the analysed period recorded significant increase, from 62.7 million in 2012, to 91.2 million in 2019. In a given sample, Germans (27.9\%), Slovenes (11.2\%) and Austrians (10.1\%) prevail in the structure of total arrivals, while Danes $(1.2 \%)$ and Finns $(0.6 \%)$ are the least represented (2012-2019). Of all countries from the sample whose inhabitants visited Croatia in 2019, the highest income (proxied by GDP per capita) was recorded for tourists arriving from Norway (92,556 USD), Denmark $(65,820$ USD) and Sweden (58,013 USD), while the lowest one was documented for tourists coming from Hungary (17,572 USD) and Poland (17,407 USD). The largest gross investment made by stakeholders involved in providing accommodation, food, catering, and other hospitality services in Croatia have been achieved during the last three observed years (i.e., 2017, 2018 and 2019) and they amounted 839, 790 and 726 million of USD respectively. During the observed period, the lowest level of corruption perception for the nine main Croatian competitor countries is reported in 2016, while the largest value of variable representing terrorism is evidenced in 2019.

Table 1 Descriptive statistics

\begin{tabular}{|c|c|c|c|c|}
\hline Variable & Mean & Std. Dev. & Min & Max \\
\hline Q & 14.69119 & 1.001664 & 12.05525 & 16.81043 \\
\hline I & 10.52164 & 0.515889 & 9.500619 & 11.43557 \\
\hline P & -0.015572 & 0.029183 & -0.102279 & 0.040365 \\
\hline Corr & 3.985837 & 0.0106581 & 3.959754 & 3.997181 \\
\hline Terr & 3.945805 & 0.0607662 & 3.832258 & 4.048882 \\
\hline Inv & 15.0123 & 0.3478587 & 14.5147 & 15.46292 \\
\hline
\end{tabular}

Source: Authors`calculations

According to the results of the correlation analysis (table 2), there is no presence of multicollinearity among analysed variables as none of the correlation coefficient is larger than 0.7 (or according to a stricter rule, larger than 0.6). The strongest correlation is recorded between price and investments and it amounted -0.56 . 
Table 2 Results of correlation analysis

\begin{tabular}{|c|c|c|c|c|c|c|}
\hline Variable & $\mathrm{Q}$ & $\mathrm{I}$ & $\mathrm{P}$ & Corr & Terr & Inv \\
\hline $\mathrm{Q}$ & 1.0000 & & & & & \\
\hline $\mathrm{I}$ & -0.4049 & 1.0000 & & & & \\
\hline $\mathrm{P}$ & -0.1196 & 0.1023 & 1.0000 & & & \\
\hline Corr & -0.0284 & 0.0006 & 0.0656 & 1.0000 & & \\
\hline Terr & 0.1123 & 0.0634 & -0.4794 & 0.0716 & 1.0000 & \\
\hline Inv & 0.1719 & 0.0767 & -0.5603 & -0.0853 & 0.6156 & 1.0000 \\
\hline
\end{tabular}

Source: Authors`calculations

The results of the estimated model for tourism demand (1) are presented in table 3. From this table it is clear that Sargan test indicates no presence of over-identifying restrictions. In addition, due to the insignificant $p$-value of $m_{1}$ and $m_{2}$ test, the null hypothesis (of no serial correlation) is accepted. As the model passed both of the presented (and earlier explained) tests, we can continue with the interpretation of the obtained results.

Table 3 Results of the dynamic panel model

\begin{tabular}{|c|c|c|}
\hline \multirow[b]{2}{*}{ Variables } & \multicolumn{2}{|c|}{ Q } \\
\hline & Coef. & $P$ \\
\hline $\mathrm{Q}_{\mathrm{t}-1}$ & 0.446671 & 0.000 \\
\hline I & 0.895632 & 0.000 \\
\hline$P$ & -1.396608 & 0.001 \\
\hline Corr. & -1.449419 & 0.000 \\
\hline Ter. & -0.478213 & 0.000 \\
\hline Inv. & 0.118504 & 0.000 \\
\hline Cons & 4.622719 & 0.013 \\
\hline No. of obs. & \multicolumn{2}{|c|}{96} \\
\hline Arellano-Bond (m1) (p-value) & \multicolumn{2}{|c|}{0.2725} \\
\hline Arellano-Bond (m2) (p-value) & \multicolumn{2}{|c|}{0.4194} \\
\hline $\begin{array}{l}\text { Sargan test } \\
\text { (p-value) }\end{array}$ & \multicolumn{2}{|c|}{0.1960} \\
\hline
\end{tabular}

Source: Authors`calculations

The value of the lagged variable $\left(\mathrm{Q}_{\mathrm{t}-1}\right)$, which represents tourism demand in previous year, is statistically significant and thus confirms the importance of incorporating the dynamism in the model specification. In line with the study [8], a lagged dependent variable can be explained as high loyalty of tourists to the selected destination as well as a crucial word-of-mouth effect on tourists' decision. Moderate value of $\delta$ coefficient (0.45) denotes that Croatian tourism industry is relatively competitive as demand for Croatian tourist product seem to have relatively moderate speed of adjustment. The signs of all coefficients are in line with our expectation and theoretical literature. In addition, all variables used in the proposed dynamic model are statistically significant at the level of $1 \%$. Positive sign of income implies that the higher level of tourist income will increase tourist arrivals in Croatia. Since the value of the income coefficient, i.e., elasticity is $0.9 \%$, a tourism product from Croatia can be consider as a normal good. Still, as this value is close to unity, it is on the edge of becoming luxury good. Similar results were recorded by [24] and [28]. In accordance with microeconomic theory, price has negative influence on tourist arrivals. The higher is the price, the lower is tourism demand (vice versa). The value of this coefficient ($1.4 \%)$ indicate that tourism demand is elastic, meaning that there is a substantial change in quantity demanded when the price of the tourism product changes. Due to the elastic demand, the best pricing strategy for hotels, apartments and other accommodations in Croatia would be to decrease a price (ceteris paribus), as on this way a higher level of revenues can be obtained. Presented results are in line with those of [8], [24], and [28]. When explaining the index of corruption, one must have in mind that higher value of this index indicates lower corruption perception. Therefore, the negative coefficient of corruption points toward proportional relationship between abroad corruption and tourist arrivals in Croatia, meaning that in the case of higher corruption perception in competitor destinations, tourists will prefer Croatia as their destination. This finding is in accordance with [14] and [15]. The same analogy can be applied for the variable terrorism. As Vision of Humanity ranks countries with high level of terrorism on the top and countries with the no terrorism on the bottom of their list, the obtained negative sign suggests that tourist arrivals in Croatia will increase in the case of higher terrorism activity in competitors' destinations. Researches of [17] and [19] also confirmed a significant impact of this variable on tourism demand. Finally, the influence of variable investments on tourism demand is positive, suggesting that any investment in accommodation, food, catering, and other hospitality services in Croatia will increase tourist arrivals. This result is in accordance with the one of [24] and [30] who were stressing the importance of taking care of tourists' well-being and the significance of the high-quality investments, as they may influence tourists' decision to visit a particular country.

\section{CONCLUSION}

Aiming to investigate the influence of different factors on tourism demand, this research used a panel dataset on 16 countries of origin and 9 competitor countries during the period from 2012 to 2019. As dynamic component is included in the formulated model, a first-differenced GMM estimator was applied in the research. The results of the performed empirical analysis showed a statistically significant value of the lagged tourism demand variable with $\delta$ coefficient of 0.45 suggesting that Croatian tourism industry is relatively competitive as speed of adjustment toward its optimal level is not so fast. The results also indicate that all variables 
encompassed by the model have statistically significant influence on tourist arrivals in Croatia, while the sign of all coefficients are in line with the relevant literature. According to the obtained value of income elasticity $(0.9 \%)$, a tourism product from Croatia can be seen as a normal good, for which the demand will grow parallel with the increase in tourists' income. On the other hand, price elasticity of $-1.4 \%$ pointed toward an elastic demand for tourist arrivals. As microeconomic theory stress that (for elastic demand) higher levels of achieved revenue for hotels, apartments and other accommodation can be obtained only with a price reduction (ceteris paribus), managers should carefully plan and implement adequate pricing strategies. Achieved values for variables terrorism and corruption suggested that in the case of higher terrorism activity or corruptions in competitors' destinations, tourist will choose Croatia as a safer and more desirable country. In that sense, an adequate marketing mix and promotion of Croatia as a safe country by the Croatian National Tourist Board and other merit institutions are of vital importance. The results also revealed the importance of the investments in hospitality as they can produce beneficial effect on tourist arrivals.

\section{REFERENCES}

[1] J. M. Perloff, Microeconomics: Theory and applications with calculus. London: Pearson, 2020, pp. 11-12.

[2] J. Fletcher, A. Fyall, D. Gilbert, S. Wanhill, Tourism principles and practice. 6th ed. London: Pearson, 2018, pp. 26-17.

[3] H. Song, G. Li, "Tourism demand modelling and forecasting - A review of recent research", Tourism Management vol. 29(2), pp. 203-220, 2008

[4] J. G. Brida, R. Scuderi, "Determinants of tourist expenditure: A review of microeconometric models", Tourism Management Perspectives vol. 6, pp. 28-40, 2013.

[5] T. Dogru, E. Sirakaya-Turk, G. I. Crouch, "Remodeling international tourism demand: Old theory and new evidence", Tourism management vol. 60 , pp. 47-55, 2017

[6] H. Song, S. F. Witt, G. Li, The advanced econometrics of tourism demand. New York: Routledge, 2009, pp. 2-7.

[7] T. Garín-Muñoz, "Inbound international tourism to Canary Islands: a dynamic panel data model", Tourism Management vol. 27, pp. 281-291, 2006.

[8] T. Garín-Muñoz "German demand for tourism in Spain", Tourism Management vol. 28, pp. 12-22, 2007.

[9] X. A. Rodríguez, F. Martínez-Roget, E. Pawlowska, "Academic tourism demand in Galicia, Spain", Tourism Management vol. 33(6), pp.15831590, 2012.

[10] J. P. Cerdeira Bento, "The determinants of international academic tourism demand in Europe", Tourism Economics vol. 20(3), pp. 611$628,2014$.

[11] H. Li, H. Song, L. Li, "A dynamic panel data analysis of climate and tourism demand: Additional evidence", Journal of Travel Research vol. 56(2), pp.158-171, 2017.

[12] Z. Lv, T. Xu, "A panel data quantile regression analysis of the impact of corruption on tourism", Current Issues in Tourism vol. 20(6), pp.603616, 2017

[13] F. Balli, H. O. Balli, R. J. Louis, "The impacts of immigrants and institutions on bilateral tourism flows", Tourism Management vol. 52, pp. 221-229, 2016.

[14] M. Poprawe, "A panel data analysis of the effect of corruption on tourism", Applied Economics, vol. 47(23), pp. 2399-2412, 2015.

[15] S. Saha, G. Yap, "Corruption and tourism: An empirical investigation in a non- linear framework", International Journal of Tourism Research vol. 17(3), pp. 272-281, 2015.
[16] J. E. Araña, C. J. León, "The impact of terrorism on tourism demand", Annals of tourism research vol. 35(2), pp. 299-315, 2008.

[17] R. Ulucak, A. G. Yücel, S. Ç. İlkay, "Dynamics of tourism demand in Turkey: Panel data analysis using gravity model", Tourism Economics vol. 26(8), pp.1394-1414, 2020.

[18] S. Saha, G. Yap, "The moderation effects of political instability and terrorism on tourism development: A cross-country panel analysis", Journal of Travel Research vol. 53(4), pp. 509-521, 2014.

[19] J. Fourie, J. Rosselló-Nadal, M. Santana-Gallego, "Fatal attraction: How security threats hurt tourism", Journal of Travel Research vol. 59(2), pp. 209-219, 2020.

[20] A. Mervar, J. E. Payne, "An analysis of foreign tourism demand for Croatian destinations: long-run elasticity estimates", Radni materijali EIZ-a, (1), pp.5-21, 2007.

[21] T. Baldigara, M. Mamula, "Modelling international tourism demand using seasonal ARIMA models", Tourism and hospitality management vol. 21(1), pp.19-31, 2015.

[22] I. Kožić, "Prognoziranje srednjoročnog dosega fizičkog turističkog prometa u Hrvatskoj”, Ekonomska misao i praksa vol. 2, pp. 419-437, 2018.

[23] L. Škuflić, I. Štoković, "Demand function for Croatian tourist product: A panel data approach", Modern Economy vol. 2(1), pp. 48-52, 2011.

[24] T. Škrinjarić, "Investigation of foreign tourism demand in Croatia using panel data analysis", Acta turistica, vol. 23(2), pp.145-173, 2011

[25] P. P. Athanasoglou, S. N. Brissimis, M. D. Delis, "Bank-specific, industry-specific and macroeconomic determinants of bank profitability", Journal of International Financial Markets, Institutions and Money vol. 18(2), pp. 121-136, 2008.

[26] M. Arellano, S. Bond, "Some Test of Specification for Panel Data, Monte Carlo Evidence and Application to Employment Equations", Review of Economic Studies vol. 58, pp. 277-297, 1991

[27] A.C. Cameron, P.K. Trivedi, Microeconometrics Using Stata, Revised Edition, A Stata Press Publication, StataCorp LP, College Station, Texas.

[28] M. Ibrahim, "The determinants of international tourism demand for Egypt: Panel data evidence.", European Journal of Economics, Finance and Administrative Sciences, vol. 30(2011), pp. 50-58, 2013.

[29] Institut za turizam. "Glavni plan i strategija razvoja turizma Republike Hrvatske. Izvještaj 3. Hrvatski turizam i konkurentsko okruženje", Institut za turizam, Zagreb [Online], Nov, 2011. Available: https://mint.gov.hr/UserDocsImages/arhiva/Izvjestaj-3-121102-IZT.pdf

[30] M. A. Nawaz, S. Hassan, "Investment and Tourism: Insights from the literature." International Journal of Economics Perspectives vol. 10(4), pp. 581-590, 2016

\section{Creative Commons Attribution License 4.0 (Attribution 4.0 International, CC BY 4.0)}

This article is published under the terms of the Creative Commons Attribution License 4.0 https://creativecommons.org/licenses/by/4.0/deed.en US 